\title{
EDITORIAL: BEYOND EAST AND WEST
}

\author{
PAUL A. PICKERING
}

\begin{abstract}
Men make their own history, but they do not make it just as they please; they do not make it under circumstances chosen by themselves, but under circumstances directly encountered, given and transmitted from the past. The tradition of all the dead generations weighs like a nightmare on the brain of the living. ${ }^{1}$ (Karl Marx)
\end{abstract}

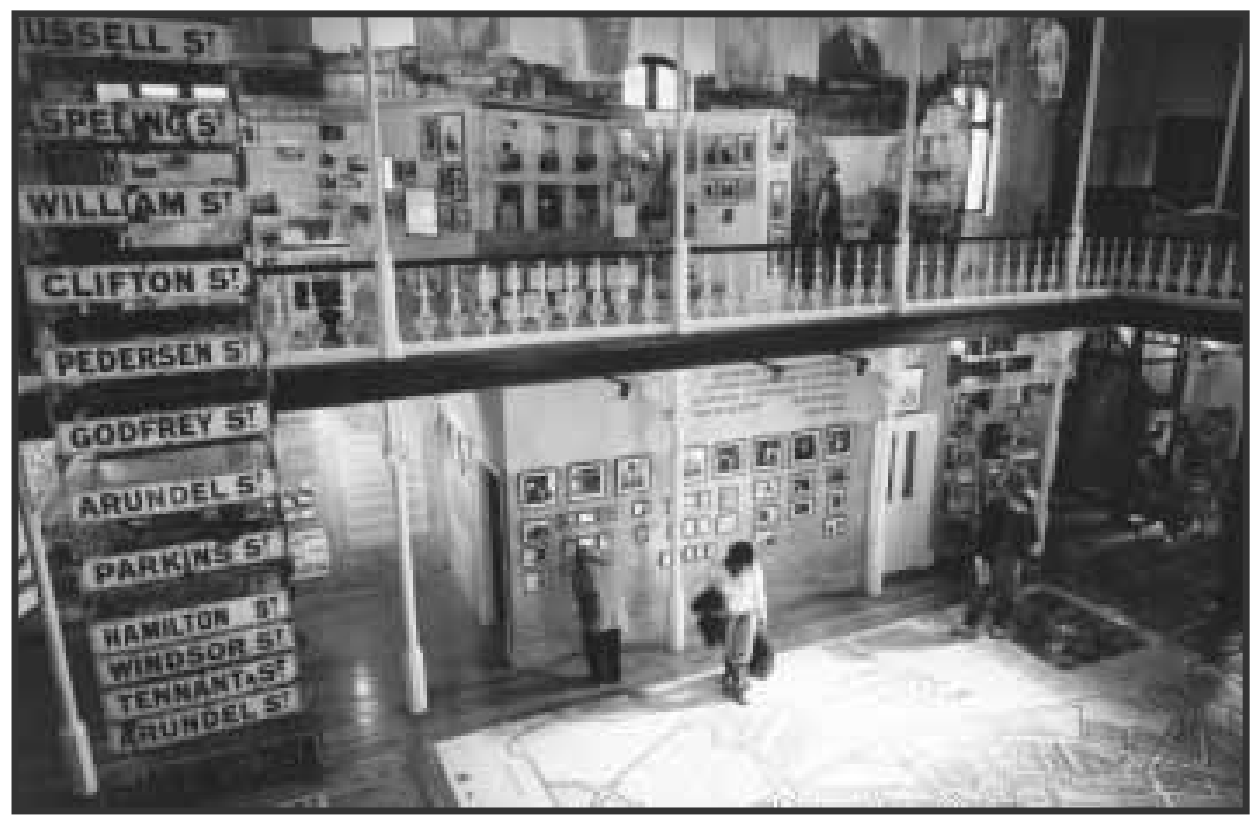

Street sign sculpture at the District Six Museum, Cape Town, South Africa. Photo: Paul Grendon, (c) District Six Museum.

$\mathrm{K}$ arl Marx was sitting at an austere desk in the British Library in the Bloomsbury district of London when he penned these well-known words, but England was not the object of his attention on that day early in 1852. Marx was actually writing for an American audience about the coup d'etat of
Louis Bonaparte - 'Napoleon the Little' that had taken place in France on 1 December of the previous year, but his words are surely apposite for many places and times. In this, the second volume of Humanities Research devoted to a consideration of the 'Museums of the Future', the contributors 
address critical issues of indigeneity, postcolonialism, cultural difference, human rights, and heritage and sustainable development, across a very broad front. In so doing they confront many of the nightmares of dead generations that perplexed Marx.

To some extent an agenda for the volume is set in the opening essay by Dipesh Chakrabarty, currently a Visiting Fellow at the Centre for Cross-Cultural Research at The Australian National University. In his thoughtful piece Chakrabarty ponders the effect of mass democracy on museums in post-colonial societies. In part he accomplishes this by examining the District Six Museum in Cape Town. Formerly a 'mixed' neighbourhood, District Six was, as Chakrabarty recounts, systematically cleared at the height of the Apartheid regime to make way for a Whites-only housing development. Since 1994 the Museum has developed as a site of communal memory for former residents and their families that not only recaptures their past but also informs their present struggles. Museums such as District Six, he writes, "more than archives and history departments, have travelled the distance needed to keep up with the changes that mark late democracies".

These broad issues are also canvassed in contributions by Murphy, Galla, Turner, and West. Reproduced here for the first time, Richard West's address to a conference at the National Museum of Australia in Canberra in February this year outlines the inclusive consultative process that went into the establishment of the Smithsonian Institution's National Museum of the American Indian, currently under construction in Washington. In making the case for extensive community involvement, "shared authority" and a "multiplicity of diverse and authoritative voices", West argues forcefully against the notion of a museum as a "precious place" where "representational or interpretative truth" is the "sanctuary of a narrowly defined and largely self-appointed museological priesthood". Engagement with minority and indigenous culture and the interface between East and West is also the agenda of Caroline Turner's contribution to the journal. Her exposition of leading Chinese and Japanese museums produces both striking points of connection and dramatic contrasts: from the lingering spectre of the rampant Red Guards smashing artefacts during the Cultural Revolution, to the lingering stench of rotting meat that literally pervaded the atmosphere at the 2000 alternative Biennale in Shanghai (appropriately entitled $F^{* * *}$ Off); from the explicit internationalism of the Japanese National Museum of Ethnology, which even found a place for the culture of the indigenous people of Hokkaido - the Ainu - long before the government revised its claim that Japan was a monocultural country, to the determined policy of engagement with Asia pursued by the Fukuoka Asian Art Museum and the Fukuoka Triennale. Clearly there is much to be learned from what Turner describes as the evolving "nonwestern museological discourse that is grounded in Asia, inclusive in both professional orientation and cross-cultural dialogue".

Turner's focus on the Asia-Pacific is shared by Murphy and Galla. Amareswar Galla presents an account of the development of the Ecomuseum at Ha Long Bay in the Quang Ninh province of Vietnam. Despite the backdrop of poverty, inadequate physical infrastructure and what he calls the "centripetal and centrifugal forces of globalisation and localisation/indigenisation", Galla's preliminary report card is overwhelmingly positive, and with good reason. Even at the development stage the Ecomuseum Hub has been internationally recognised as world's best practice as an innovative model for promoting heritage economics without compromising conservation values. Economic development and poverty alleviation, according to Galla, are not incompatible with cultural and environmental self-determination and heritage conservation. Bernice Murphy's essay explores what she calls the "subtleties 
and cross-cultural dialogue and imagination" in the design and development of the Tjibaou Centre in Nouméa in New Caledonia. Murphy demonstrates how the architect, Renzo Piano, drew upon Kanak traditions and history whilst avoiding the dangers of cultural projection and the cliché. Named in honour of the assassinated Kanak leader, Jean-Marie Tjibaou, the resultant complex is, she claims, "exceptional in the world of contemporary architecture" in that it both reflects Tjibaou's own rejection of an 'archaeological' conception of culture, and the aspirations of a colonised indigenous population to "regain a sense of agency in shaping their destiny".

Australia's sense of its own past - and the practices involved in presenting it - is also challenged in two important contributions in this issue by Karskens and Read. Karskens provides an overview of what she calls "a new collaborative and integrated approach to urban archaeology" that has recently been employed in the Cumberland/ Gloucester Street project in Sydney. Artefacts, she insists, "still hang in the uneasy, as yet unresolved space triangulated between the idea of museums as repositories for scientific research, their aestheticallyinclined collection and presentation, curation and exhibition regimes, and the more recent, potentially radical inroads of social history". In seeking a way forward Karskens argues that we can no longer "simply dig up the past", and she supports this claim by demonstrating how collaborative urban archaeology can be used to challenge much received wisdom about early Sydney.
Peter Read's searing account of a workshop on Top End history that he presented to the annual conference of Adult Learning Australia in 2001, is a reminder — if one was needed - that many of the issues raised by other contributions to this edition of Humanities Research also directly confront Australia. "Australians cannot achieve true reconciliation", he writes, "until they acknowledge the past, nor acknowledge the past until they know actually what happened". Knowing what happened, he suggests, is less difficult than is sometimes portrayed, but no less painful. There are many 'nightmares' for Australians to come to terms with. In his influential book, How Societies Remember, written, in part, during a visiting fellowship at the Humanities Research Centre, Paul Connerton has argued that "our images of the past commonly serve to legitimate a present social order". ${ }^{2}$ If Connerton is correct museums will, inevitably, continue to present consensual images of the past, but, as the contributions to this volume make clear, the museum of the future must also challenge unitary views of history. The museum of the future must speak with more than one voice.

Endnotes

1 K. Marx, The 18th Brumaire of Louis Bonaparte, (1852, New York, 1963), p. 15.

2 P. Connerton, How Societies Remember, (Cambridge, 1989), p. 3. 